\title{
Originals
}

\section{Assessment of an Algorithm for the Artificial B-Cell Using the Normal Insulin-Glucose Relationship in Diabetic Dogs and Men}

\author{
U. Fischer, E. Jutzi, H. Bombor, E.-J. Freyse, E. Salzsieder, G. Albrecht, W. Besch, and W. Bruns \\ Central Institute for Diabetes "Gerhardt Katsch", Karlsburg, GDR
}

\begin{abstract}
Summary. Insulin secretion rates after glucose loading were calculated from peripheral venous IRI concentrations considering half life and distribution space of exogenous insulin in normal men and dogs. The coefficients of multiple linear regression analysis between insulin secretion rates and plasma glucose (level and order and rate of change) were used as algorithm parameters in glucose-controlled insulin infusions. These were carried out in each dog based on individual estimations before the induction of diabetes but in the diabetic patients based on values derived from a group of normal subjects. Using this formula, nearly normal patterns of glucose and of insulin were observed in diabetic men and dogs under basal conditions and after IV glucose loading but not after meals. This algorithm enables selection of the parameters prospectively. The effect of a parameter combination depends on insulin sensitivity and it should be appropriately adapted. In the diabetic patients there was no predictable influence of the brittle or stable characteristics of the disease nor of insulin antibodies on the glucose curves obtained with glucose controlled insulin infusions.
\end{abstract}

Key words: Artificial B-cell, algorithm, glucose-insulin relationship, regression analysis, insulin secretion, insulin half-life, human diabetes mellitus, experimental diabetes mellitus.

At present optimal control of blood glucose concentration in diabetes can be achieved by a continuous intravenous glucose-controlled insulin infusion $(\mathrm{GCII})^{1}[21,32]$. The infusion systems used (GCIIS)

\footnotetext{
1 Abbreviations: GCII - glucose-controlled insulin infusion; GCIIS - glucose-controlled insulin infusion system; IRI immunoreactive insulin; OGTT - oral glucose tolerance test; $\mathrm{PG}$ - plasma glucose
}

apply the tanh function $[3,4,22,36]$ or other nonlinear $[6,7]$ or linear $[21,23]$ algorithms to delineate the glucose-insulin relationship. Improvement of some of these algorithms has been achieved by socalled dynamic or derivative control $[7,21]$. Appropriate algorithm parameters can, however, only be selected empirically. Thus we earlier derived a formula for the artificial B-cell based on a multiple regression analysis between plasma glucose and insulin secretion rates in response to a glucose stimulus in normal subjects [11]. The resulting regression coefficients provided the algorithm parameters for GCII in diabetes. Principally, this method allows the prospective and individual evaluation of the constants.

This paper deals with the further experimental investigation in men and dogs and preliminary clinical application of a GCIIS based on such algorithms.

\section{Materials and Methods}

The groups of experimental animals and men used in the experiments are show in Table 1 as are the investigations performed. One group of dogs of both sexes was investigated before and after the induction of diabetes, another group was observed without diabetes only; three different groups of normal men were tested, and one group of diabetic patients (Table 2) was investigated.

\section{Animal Experiments}

Two to four weeks before the induction of diabetes the dogs (normal group (1)) had been submitted to at least one glucose test (OGTT $1.0 \mathrm{~g} / \mathrm{kg}$ or non-primed IV glucose infusion with 12 or $16 \mathrm{mg} / \mathrm{kg} / \mathrm{min}$ for $60 \mathrm{~min}$ ) and to an estimation of insulin half-life and distribution space by $\Gamma \mathrm{V}$ injection of $50 \mathrm{mU} / \mathrm{kg}$ Actrapid insulin. Details of these procedures have been described previously [11]. The animals were made diabetic by partial pancreatectomy and intraoperative administration of $2 \mathrm{mg} / \mathrm{kg}$ streptozotocin (Upjohn, Kalamazoo, lot No. BV 71-221) into the pancreaticoduodenal artery. If necessary another streptozotocin dose $(15 \mathrm{mg} / \mathrm{kg})$ was given intravenously three to six days after the operation.

The diabetes was treated with three daily injections of soluble pork insulin (Actrapid-MC). The animals received two or three 
Table 1. Experimental groups

\begin{tabular}{|c|c|c|c|c|c|c|c|}
\hline & & $\mathrm{n}$ & $\begin{array}{l}\text { Body } \\
\text { weight } \\
(\mathrm{kg})\end{array}$ & Age & $\begin{array}{l}\text { Duration } \\
\text { of } \\
\text { diabetes }\end{array}$ & $\begin{array}{l}\text { Type } \\
\text { of } \\
\text { investigation }\end{array}$ & $\begin{array}{l}\text { Purpose of the } \\
\text { investigation }\end{array}$ \\
\hline \multirow[t]{3}{*}{ Dogs } & Normal (1) & 12 & $29 \pm 1$ & $\begin{array}{l}28 \pm 3 \\
\text { months }\end{array}$ & - & $\begin{array}{l}\text { OGTT, IV glucose infusion, } \\
\text { IV insulin injection, } \\
\text { mixed meal }\end{array}$ & $\begin{array}{l}\text { Algorithm parameters, insulin half life, } \\
\text { comparison of the PG curves with those } \\
\text { in diabetics on GCII }\end{array}$ \\
\hline & $\begin{array}{l}\text { The same } \\
\text { animals } \\
\text { made diabetic }\end{array}$ & 12 & $29 \pm 1$ & $\begin{array}{l}40 \pm 3 \\
\text { months }\end{array}$ & $\begin{array}{l}10 \pm 2^{\mathrm{a}} \\
\text { months }\end{array}$ & $\begin{array}{l}\text { GCII with meals } \\
\text { or glucose loads }\end{array}$ & $\begin{array}{l}\text { Comparison with normals of diabetics } \\
\text { treated with GCII programmed individually }\end{array}$ \\
\hline & Normal (2) & 10 & $31 \pm 1$ & $\begin{array}{l}27 \pm 4 \\
\text { months }\end{array}$ & - & $\begin{array}{l}\text { Direct in vivo } \\
\text { assessment of } \\
\text { insulin secretion rate }\end{array}$ & $\begin{array}{l}\text { Comparison with the insulin secretion } \\
\text { rates as calculated by formula (1) } \\
\text { from the peripheral venous IRI } \\
\text { concentration }\end{array}$ \\
\hline \multirow[t]{4}{*}{ Men } & Normal (1) & 7 & $68 \pm 3^{\mathrm{b}}$ & $\begin{array}{l}26 \pm 1 \\
\text { years }\end{array}$ & - & OGTT & Algorithm parameters \\
\hline & Normal (2) & 8 & $59 \pm 3^{b}$ & $\begin{array}{l}22 \pm 1 \\
\text { years }\end{array}$ & - & IV glucose infusion & Algorithm parameters \\
\hline & Normal (3) & 5 & $70 \pm 4^{b}$ & $\begin{array}{l}31 \pm 4 \\
\text { years }\end{array}$ & - & Mixed meal & $\begin{array}{l}\text { Comparison with GCII action in } \\
\text { diabetics }\end{array}$ \\
\hline & Diabetics $^{c}$ & 12 & $67 \pm 2^{b}$ & $\begin{array}{l}32 \pm 2 \\
\text { years }\end{array}$ & $\begin{array}{l}14 \pm 2 \\
\text { years }\end{array}$ & $\begin{array}{l}\text { IV insulin injection, } \\
\text { GCII with mixed meals }\end{array}$ & $\begin{array}{l}\text { Insulin half life, } \\
\text { comparison with normals of diabetics } \\
\text { treated with GCII using a standard } \\
\text { algorithm }\end{array}$ \\
\hline
\end{tabular}

a Mean duration during the whole time of the study

b All values within the limits of $100 \pm 3 \%$ (mean \pm SEM) of the ideal weight

${ }^{c}$ For details see Table 2

${ }^{d}$ See Methods section for details

meals per day (depending on body weight) consisting of meat and oats and exercised for three $\mathrm{h} /$ day. The experimental observations in the diabetic state were performed in the conscious animals starting at $0700 \mathrm{~h}, 13 \mathrm{~h}$ after the last meal and the last SC injection of insulin. The animals had a chronically implanted jugular venous catheter for the insulin infusions. They were treated by GCII for 8 to $40 \mathrm{~h}$ as described below. During GCII the animals were given OGTT's, glucose infusion tests, or normal meals (1000 g meat). Not all animals were submitted to each test. At the time of study there were no circulating insulin antibodies, thus IRI represented the concentrations of free biologically active insulin, as in normal dogs.

In addition laparotomies were performed in non-diabetic dogs (normal group (2)) under general anaesthesia. Indwelling catheters for sampling of portal, intestinal, hepatic and peripheral venous and arterial blood for IRI analyses were inserted as were non-cannulating flowprobes for the electromagnetic measurement of pancreatic and hepatic blood flows. From these measurements the rates of net pancreatic insulin secretion and the hepatic balances of insulin were estimated and they were compared with insulin secretion rate calculations as presented below. The details of this experimental procedure and of the calculations have been described previously $[9,12]$.

\section{Human Studies}

The three groups of normal male volunteers (Table 1) were investigated to obtain algorithm parameters and normal plasma glucose curves after a meal. They were medical students or members of the laboratory staff. GCII was realized in 12 male diabetic patients (Table 2) during the first week of their hospital stay which was routine for stabilisation of diabetes. No other drugs were taken by the patients and by the control persons. All healthy subjects and all patients taking part were informed according to the declaration of Helsinki (38) of the nature of the study and gave their consent to participate. Ketosis-prone patients with a relatively high need of insulin, and with difficult glycaemic control due to extreme intraand inter-day variability of their plasma glucose levels in response to constant insulin therapy were defined as "brittle diabetics".

The GCII studies were performed at bed-rest and were started at $0400 \mathrm{~h}, 6 \mathrm{~h}$ after the last SC dose of soluble insulin. By varying this dose the plasma glucose level at the beginning of the experiment was intentionally varied. For getting blood specimens and for performing the infusions the patients had two indwelling plastic cannulas in peripheral veins and were treated by GCII for 5 to $11 \mathrm{~h}$ as described below. The initial glucose normalisation, the fasting steady state glucose level (any alterations smaller than $\pm 3 \mathrm{mg} / \mathrm{dl}$ ) reached on GCII, and the response to one or two mixed standard meals of $500 \mathrm{Cal}$ ( $60 \mathrm{~g}$ carbohydrates, $15 \mathrm{~g}$ fat, $27 \mathrm{~g}$ protein) were recorded. Normal subjects received similar mixed meals and also oral glucose tolerance tests.

\section{Analyses, Algorithm and Glucose-controlled Insulin Infusion}

In all experiments plasma glucose (Beckman-Analyzer ${ }^{\sqrt{B}}$ ) was measured every 2.5 or $5 \mathrm{~min}$. For the estimation of plasma IRI (40) the samples were incubated for $20 \mathrm{~h}$ in triplicate with antibody at $22^{\circ} \mathrm{C}$ and thereafter with tracer insulin for $90 \mathrm{~min}$. Human insulin (WHO - standard, Code 66/304) was used as standard. The antibody-bound fraction was precipitated with ethanol in a final concentration of $77 \%$. Day-to-day precision was $8.4 \%$ at 
Table 2. General characteristics of the patients investigated. All males. The presence of insulin antibodies was demonstrated qualitatively in cases 3,5 and 9

\begin{tabular}{|c|c|c|c|c|c|c|c|c|c|}
\hline \multirow[t]{2}{*}{ Patient } & \multirow{2}{*}{$\begin{array}{l}\text { Age } \\
\text { [years] }\end{array}$} & \multirow{2}{*}{$\begin{array}{l}\text { Duration of } \\
\text { diabetes } \\
\text { [years] }\end{array}$} & \multirow{2}{*}{$\begin{array}{l}\% \text { ideal } \\
\text { body } \\
\text { weight }\end{array}$} & \multirow{2}{*}{$\begin{array}{l}\text { Daily } \\
\text { SC insulin } \\
\text { dose [IU] }\end{array}$} & \multicolumn{2}{|c|}{ Plasma glucose $[\mathrm{mg} / \mathrm{dl}]$} & \multirow{2}{*}{$\begin{array}{l}\text { Brittle } \\
\text { or stable }\end{array}$} & \multirow{2}{*}{$\begin{array}{l}\text { Serum } \\
\text { creatinine } \\
{[\mu \mathrm{mol} / 1]}\end{array}$} & \multirow{2}{*}{$\begin{array}{l}\text { Retino- } \\
\text { pathy }\end{array}$} \\
\hline & & & & & $\begin{array}{l}\text { Daily }{ }^{\mathrm{a}} \\
\text { mean }\end{array}$ & range & & & \\
\hline 1 & 42 & 19 & 96 & 38 & 181 & $(286-43)$ & brittle & 84 & I \\
\hline 2 & 27 & 13 & 94 & 26 & 248 & $(325-156)$ & stable & 97 & I \\
\hline 3 & 28 & 14 & 95 & 42 & 244 & $(426-109)$ & brittle & 90 & 0 \\
\hline 4 & 34 & 21 & 102 & 60 & 295 & $(494-156)$ & brittle & 71 & III \\
\hline 5 & 36 & 16 & 105 & 52 & 261 & $(359-120)$ & brittle & 90 & I \\
\hline 6 & 34 & 2 & 103 & 32 & 257 & $(325-146)$ & stable & 77 & 0 \\
\hline 7 & 28 & $1 \overline{7}$ & 126 & 58 & 240 & $(484-68)$ & brittle & 104 & I \\
\hline 8 & 34 & 13 & 103 & 38 & 342 & $(411-283)$ & brittle & 83 & $\mathrm{I}$ \\
\hline 9 & 22 & 2 & 94 & 32 & 207 & $(286-62)$ & stable & 76 & 0 \\
\hline 10 & 36 & 19 & 89 & 64 & 155 & $(361-55)$ & brittle & 80 & II \\
\hline 11 & 37 & 18 & 94 & 52 & 307 & (463-198) & brittle & 80 & II \\
\hline 12 & 23 & 11 & 98 & 52 & 248 & $(390-99)$ & brittle & 88 & 0 \\
\hline
\end{tabular}

a 9 analyses within 24 hours

${ }^{\mathrm{b}} 0$ - no retinopathy; I to III, progressive severity of retinopathy

$24.9 \mu \mathrm{U} / \mathrm{ml}$, and $6.8 \%$ at $93.4 \mu \mathrm{U} / \mathrm{ml}$. The lower detection limit was $3.2 \mu \mathrm{U} / \mathrm{ml}$ given as $2 \mathrm{SD}$ of the zero control samples. Insulin antibodies were estimated by incubating plasma with ${ }^{125} \mathrm{I}$-insulin at $22^{\circ} \mathrm{C}$ for $2 \mathrm{~h}$, using normal plasma as control. Free and antibodybound iodoinsulin were separated by ethanol precipitation. If antibodies were present in the sample the ${ }^{125}$ I-insulin binding was significantly $(p<0.01)$ higher than that of the control sera.

From a plot of log IRI against time after IV insulin injection, the distribution space of insulin and the half-life of exogenous insulin were obtained.

Using the IRI curves of normal subjects after glucose loading insulin secretion rates were calculated at each interval (for details [11]):

CISR $=F \cdot$ IS $\left[\right.$ IRI $_{t}+\Delta t-$ IRI $\left._{t}\left(\mathrm{e}^{-0.693 \cdot \Delta \mathrm{t} / t}\right)\right]$

CISR = calculated insulin secretion rate $[\mathrm{mU} / \Delta \mathrm{t}]$,

$\mathrm{F}=$ constant for the immediate hepatic insulin uptake from the total (portal + arterial) inflow (Table 3),

IS $=$ distribution space of exogenous insulin $[\mathrm{ml} / \mathrm{kg}$,

$\tau \quad=$ half life of exogenous insulin [min],

IRI $_{t}=a$ value of IRI and of PG at the experimental time $t$,

$\mathrm{PG}_{\mathrm{t}}$

$\Delta \mathrm{t}=$ measuring interval $[\mathrm{min}]$.

Based on these data and on the simultaneous plasma glucose determinations three components of peripheral insulin supply were defined by multiple regression analysis:

CISR $=I D=a_{0}+a_{1}\left(P_{t}+\Delta t-P_{b}\right)+a_{2}\left(P_{t}+\Delta t-P G_{t}\right)(2)$

ID = rate of insulin administration in GCII $[\mathrm{mU} / \Delta \mathrm{t}$,

$\mathrm{PG}_{\mathrm{b}}=$ desired basal $\mathrm{PG}$ level [mg/dl],

$\mathrm{a}_{\mathrm{a}} \quad=$ basal secretion rate $[\mathrm{mU} / \Delta \mathrm{t}]$,

$\mathrm{a}_{1}=$ regression coefficient for insulin secretion depending proportionally on the glucose level $[\mathrm{mU} / \Delta \mathrm{t} /$ $\left.\mathrm{mg} \cdot \mathrm{dl}^{-1}\right]$,

$\mathrm{a}_{2} \quad=$ regression coefficient for insulin secretion depending both on the rate and on the order of the change of $P G$ $\left[\mathrm{mU} / \mathrm{mg} \cdot \mathrm{dl}^{-1} \Delta \mathrm{t}\right]$.

For preparing the original data the early glucose-independent IRI increase during an OGTT [10] was not considered, and a sliding fit technique (moving average over three values) was used.

These three regression coefficients were used as indices for insulin dosage during GCII. They were taken individually in dogs and as the "mean normal human parameters" in the patients. Based on the coefficients, dosage matrices were obtained, consid-

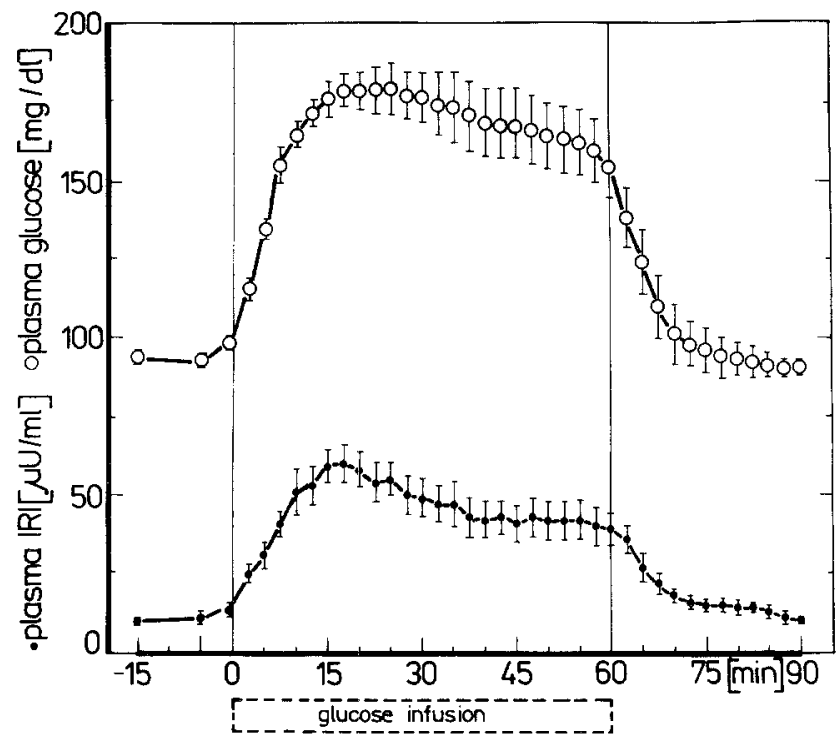

Fig. 1. Plasma glucose $(\mathrm{O}-\mathrm{O})$ and IRI $(-0)$ concentrations in 12 normal dogs before, during and after an IV glucose infusion of $60 \mathrm{~min}(16 \mathrm{mg} / \mathrm{kg} / \mathrm{min})$. Mean $\pm \mathrm{SEM}$

ering $\Delta \mathrm{t}$, the body weight of the subject to be treated, and the concentration of the insulin solution (in most cases $120 \mathrm{mU} / \mathrm{ml}$ in $0.154 \mathrm{~mol} / \mathrm{l}$ saline with $6 \% \mathrm{v} / \mathrm{v}$ mixed canine normal serum or with $4 \mathrm{~g} / 1$ human albumin respectively).

Insulin doses were selected at a self-constructed programmer [34] controlling an external infusion pump (Infumat type 5157, MTA Kutesz, Hungary or Perfusor E, Braun-Melsungen, FRG). The infusion pattern consisted of alternating intervals with $2.5 \mathrm{~min}$ of a glucose-dependent dosage and $2.5 \mathrm{~min}$ of a glucose-independent basal dose $\left(a_{0}\right)$. Analytical specimens for PG and IRI were obtained during the basal infusion periods. The whole delay between any glucose alteration and the resulting insulin dose was $2 \mathrm{~min}$. The infusion was performed both in a rate-variable flow or in the form of constant-rate pulses of a variable duration. When appropriate means \pm SEM values are given. 


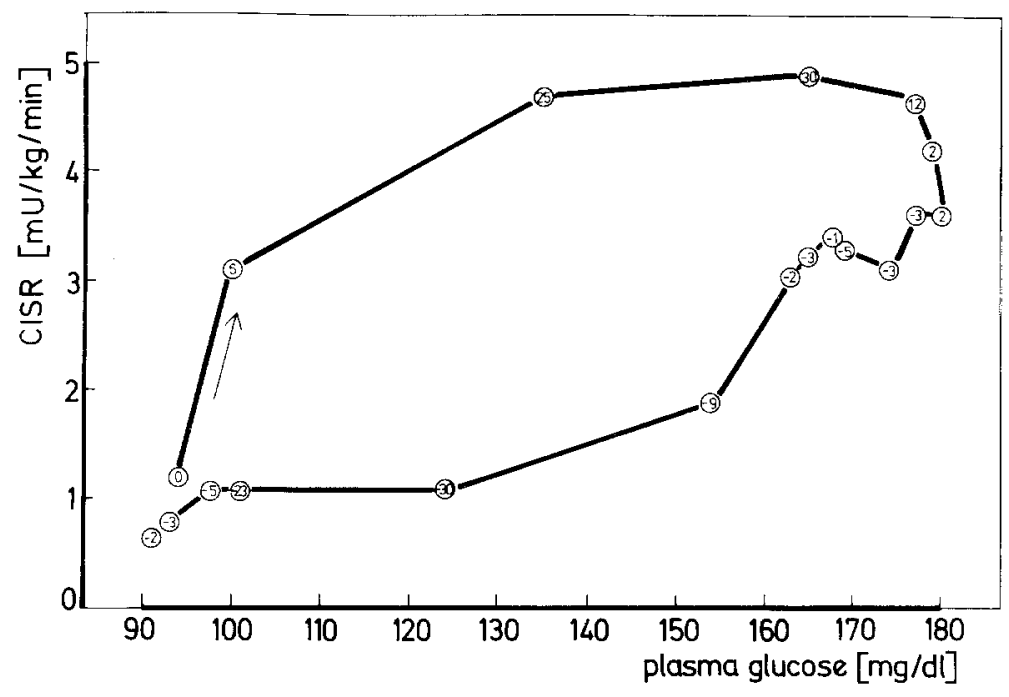

Fig. 2. Relation between the calculated insulin secretion rates (CISR) and the plasma glucose values with respect to the changes of plasma glucose during and after an IV glucose infusion in normal dogs. The values were taken from the mean curve presented in Figure 1 for intervals of 5 min beginning at -5 min. CISR was calculated according to formula (1) (see Methods)

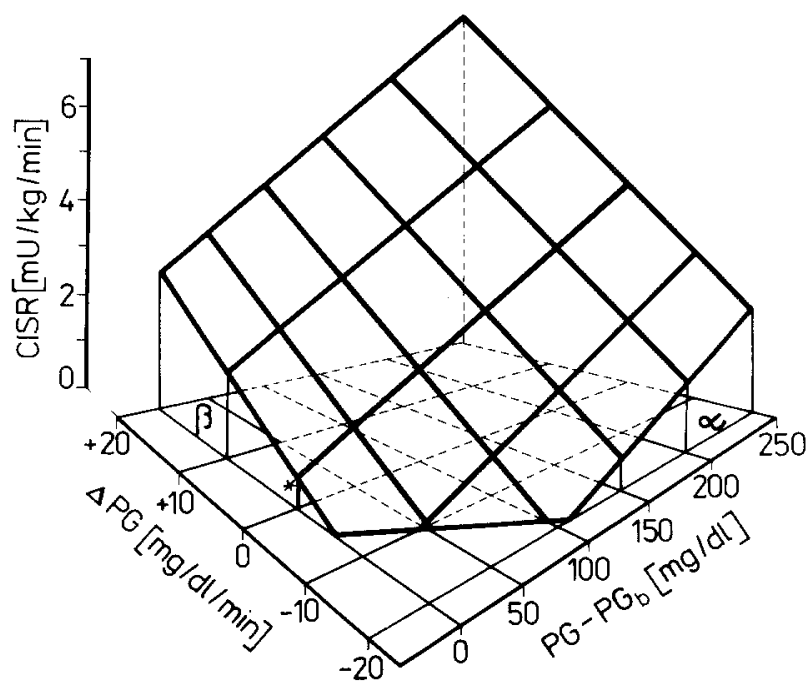

Fig. 3. Multiple regression analysis between the calculated insulin secretion rates (CISR), the difference of the actual to the basal PG value $\left(\mathrm{PG}-\mathrm{PG}_{\mathrm{b}}\right)$, and the rate of change of PG $(\Delta \mathrm{PG})$. The CISR and $P G$ data were taken from the Figures 1 and 2 (IV glucose infusion in normal dogs, mean curve). Regression coefficients: tan $\alpha=\mathrm{a}_{1}, \tan \beta=\mathrm{a}_{2}$, the asterisk denotes the basal insulin secretion rate $a_{0}$. For comments and the numerical values see Table 4

\section{Results}

\section{Experimental Proof of the Algorithm}

In Figures 1-3 the insulin-glucose algorithm is graphically derived, based on data obtained from IV glucose infusions in normal dogs (Fig. 1). The apparent insulin secretion rates were calculated for each interval applying formula (1). These calculated insulin secretion rates depend not only on the actual plasma glucose level but also on the order and the rate of its change. This is demonstrated in Figure 2 using the mean curve of Figure 1. The numbers in the circles of Figure 2 denote the $\mathrm{PG}$ changes in the intervals; the coordinates of the circles are determined by a given insulin secretion rate and by the related PG level. It can be seen that at a given PG level the yield of insulin increases when the glucose concentration was increasing during the preceding interval. Thus multiple regression analysis was performed between the insulin secretion rates and the PG level and its rate of change. The difference between actual and basal PG was taken as a figure of the glucose level. The mean basal PG (Tables 4 and 6) concentration was defined as $90 \mathrm{mg} / \mathrm{dl}$ if no individual value differed by more than $8 \mathrm{mg} / \mathrm{dl}$ from this. In the three-dimensional graph (Fig. 3) the resulting regression function according to formula (2) is represented by a plane inclined by two angles. The tangent values of these angles give the regression coefficients $a_{1}$ and $a_{2}$ und the insulin secretion rate at the not changing basal PG is $\mathrm{a}_{\mathrm{o}}$. When in GCII $\left(\mathrm{PG}-\mathrm{PG}_{\mathrm{b}}\right.$ ) is $<0$ the coefficient $a_{1}$ reduces the insulin dose to be infused as does $a_{2}$ when $\left(P_{t+\Delta t}-P G_{t}\right)$ is $<0$. The upper limit for the validity of this algorithm was fixed at $\mathrm{PG}=400 \mathrm{mg} / \mathrm{dl}$. Higher values were assumed to be in the saturation range. During normal use however, such high values were never reached.

One crucial point in the parameter estimation is the assessment of the calculated insulin secretion rate. Pancreatic and hepatic blood flow recordings combined with pre- and postpancreatic and pre- and posthepatic IRI analyses provide the possibility to control these estimates directly. Table 3 demonstrates that $50 \%$ of hepatic (arterial + portal) insulin inflow were taken up in the liver of non-diabetic anaesthetised dogs both during normoglycaemia/ normoinsulinaemia and during steady state hyperglycaemia/hyperinsulinaemia. This was considered in 
Table 3. Insulin secretion rates and hepatic insulin balances in non-diabetic, anaesthetised, laparotomised dogs. Insulin secretion rates were estimated as the product of pancreatic blood flow and of arteriovenous IRI concentration difference; hepatic insulin inflow was estimated as the sum of portal and arterial inflows (each variable was the product of concentration and of the respective blood flow); hepatic insulin outflow was the product of hepatic venous IRI and of the portal + hepatic arterial blood flows. All blood flow monitorings were done continuously by a non-cannulating electromagnetic flowprobe. Each individual was considered with the mean of 3 estimates in intervals of $5 \mathrm{~min}$ performed before or at the end of an IV glucose infusion $(30 \mathrm{mg} / \mathrm{kg} / \mathrm{min} \times 30 \mathrm{~min})$. The data represent the mean \pm SEM of 10 animals (weight $31 \pm$ $1 \mathrm{~kg}$ )

\begin{tabular}{lrrl}
\hline & Fasting & $\begin{array}{l}\text { Glucose } \\
\text { infusion }\end{array}$ & Significance \\
\hline $\begin{array}{l}\text { Arterial plasma } \\
\text { glucose [mg/dl] }\end{array}$ & $116 \pm 7$ & $412 \pm 16$ & $\mathrm{p}<0.01$ \\
$\begin{array}{l}\text { Arterial plasma } \\
\text { IRI [uU/ml] }\end{array}$ & $29 \pm 4$ & $143 \pm 8$ & $\mathrm{p}<0.01$ \\
$\begin{array}{l}\text { Pancreatic insulin } \\
\text { secretion [mU/min] }\end{array}$ & $5.6 \pm 1.6$ & $30.0 \pm 6.2$ & $\mathrm{p}<0.01$ \\
$\begin{array}{l}\text { Hepatic insulin } \\
\text { inflow [mU/min] }\end{array}$ & $17.6 \pm 3.0$ & $86.3 \pm 11.7$ & $\mathrm{p}<0.01$ \\
$\begin{array}{l}\text { Hepatic insulin } \\
\text { outflow [mU/min] }\end{array}$ & $8.0 \pm 1.9$ & $42.0 \pm 6.3$ & $\mathrm{p}<0.01$ \\
$\begin{array}{l}\text { Hepatic insulin } \\
\text { uptake [\%] }\end{array}$ & $51.5 \pm 6.2$ & $49.0 \pm 4.1$ & \\
\hline
\end{tabular}

the calculation of insulin secretion rates from peripheral venous IRI concentrations by the factor $F$ $=2$ in formula (1).

In Figure 4 directly estimated insulin secretion rates are compared with the calculated secreted rates, there was good agreement. Additionally the measurement of IRI concentration during a GCII provides the possibility to compare the real insulin dosage (ID) per interval $(\Delta t)$ with that calculated from peripheral venous IRI concentration (apparent CISR) in diabetic dogs with no insulin antibodies. Theoretically both these figures should give identical data. From the experiments demonstrated in Figure 5 the following correlation was estimated:

$\mathrm{ID}=0.85 \cdot \mathrm{CISR}-1.0(\mathrm{n}=112, \mathrm{r}=0.89)[\mathrm{mU} /$ $5 \mathrm{~min}$.].

Thus the posthepatic rate of insulin supply can be estimated accurately from peripheral venous IRI.

\section{Individual Algorithm Parameters in Dogs}

Table 4 shows the algorithm parameters of normal dogs. There were no significant differences between the estimates from OGTT and from IV glucose infusions respectively. The values, however, showed considerable intraindividual variation when the animals

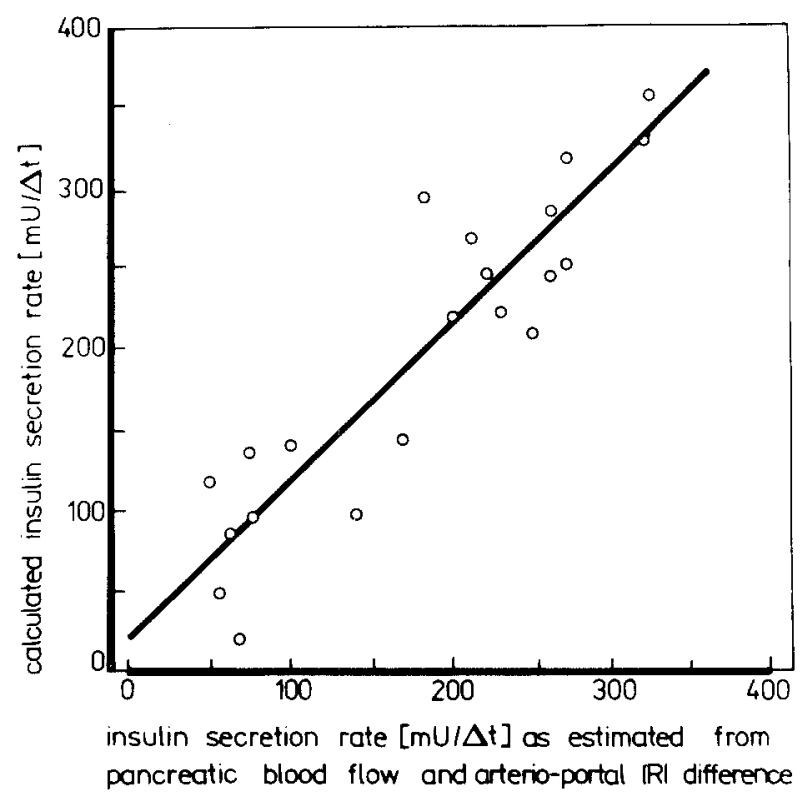

Fig. 4. Relation between directly estimated insulin secretion rates ( $x$ axis) and those calculated from the peripheral venous IRI concentrations according to formula (1) (y axis) in an anaesthetised laparotomised dog bearing multiple catheters and electromagnetic blood flowprobes. A primed IV glucose infusion was given for $120 \mathrm{~min}$ (priming dose $250 \mathrm{mg} / \mathrm{kg}$, infusion $15 \mathrm{mg} / \mathrm{kg} / \mathrm{min}$ ), $\Delta \mathrm{t}$ is between 1 and $10 \mathrm{~min}$ from 0 to $180 \mathrm{~min}$. Body weight $22.6 \mathrm{~kg}$, insulin half life $4.0 \mathrm{~min}$, insulin space $160 \mathrm{ml} / \mathrm{kg}$. The regression is $y=20.3+0.99 x(r=0.90)$

were investigated at weekly intervals. This was applicable to both the basal and the glucose-dependent insulin yield. The interindividual parameter range was within the same range. The coefficients of variation were $64 \%\left(a_{0}\right), 45 \%\left(a_{1}\right)$, and $52 \%\left(a_{2}\right)$ respectively.

The insulin-glucose regression coefficients estimated in this way served as algorithm parameters in GCII after induction of diabetes. In dogs only the individually estimated parameters were used. Most animals exhibited the same PG curves and nearly the same IRI curves as in the non-diabetic state when they were submitted to a non-primed glucose infusion four to five hours after the beginning of a GCII (Fig. 5). The total insulin dose infused did not differ from that amount evaluated from the calculated insulin secretion rate (formula (1)) before induction of diabetes in the same animals. As was expected from the delay in glucose measurement and insulin administration both the dosage pattern and the IRI curve were somewhat delayed in relation to the normal curves.

Some of the diabetic dogs did not react with normal glucose curves to the individually estimated algorithm parameters. One example is presented in Table 5. In this case the animal's own formula as evaluated from test 1 did not allow reproduction of a 


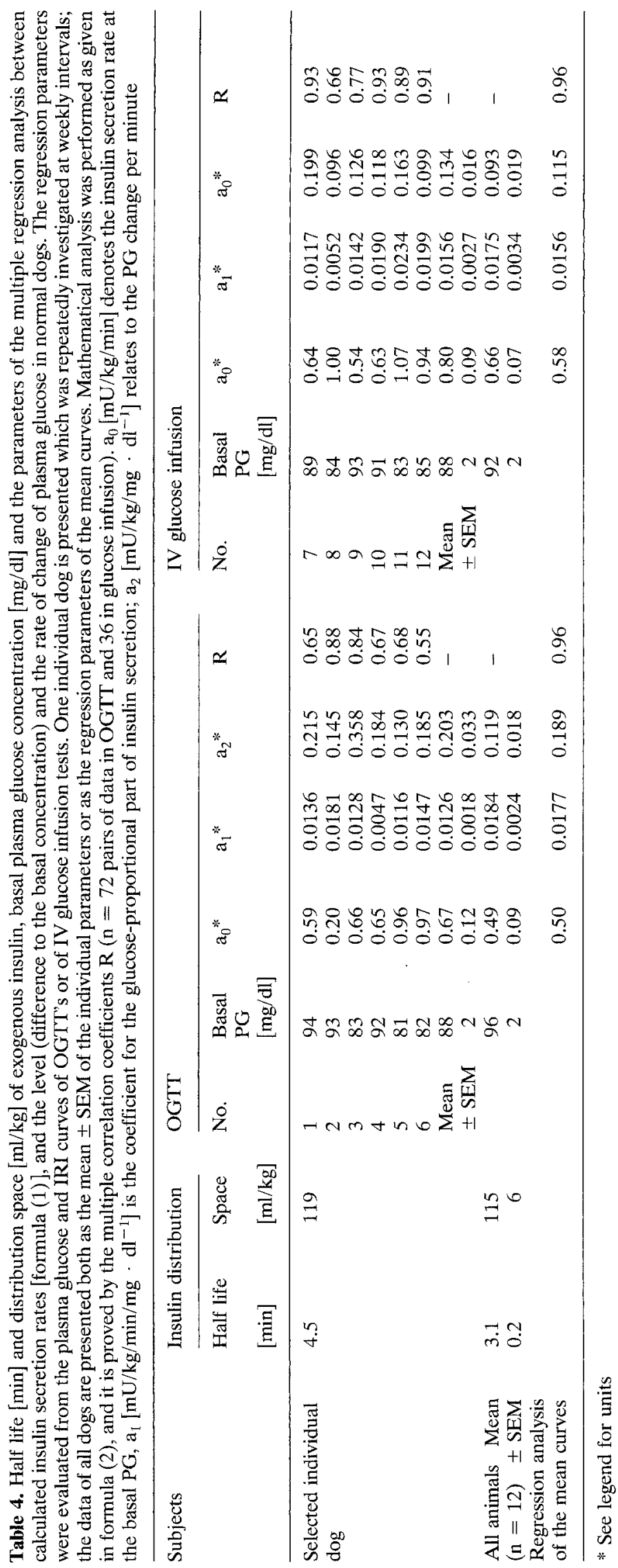

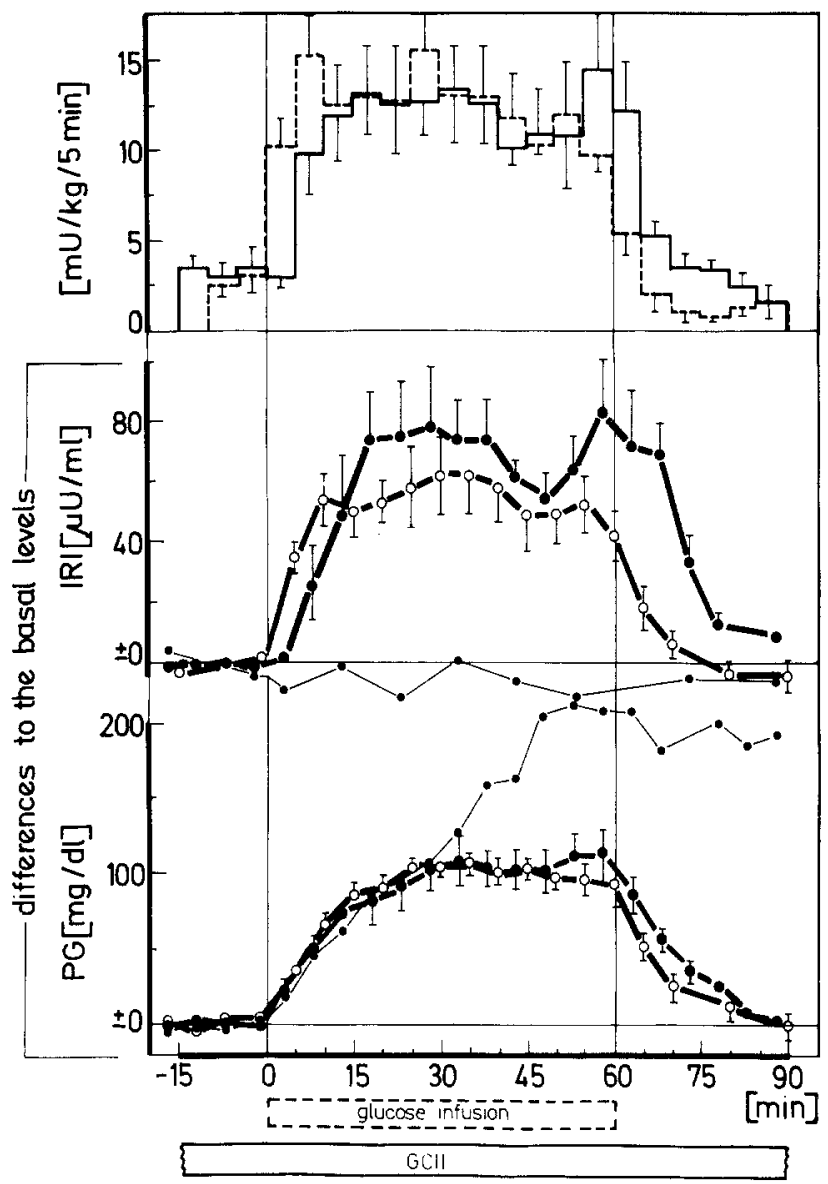

Fig. 5. Non-primed IV glucose infusion in 4 dogs before diabetes $(\mathrm{O}-\mathrm{O})$ and with GCII after induction of diabetes (-) , one animal was additionally investigated after induction of diabetes but with the GCII interrupted when starting the glucose infusion $(\bullet)$. Results are shown as increments of the PG and IRI values from those found at the beginning of the test (mean \pm SEM). The upper part shows the insulin secretion rates [calculated with formula (1)] before diabetes (-- ) and the insulin dosage pattern in GCII (-). Pretest values: PG $98 \pm 2 \mathrm{mg} / \mathrm{dl}$ (controls), $107 \pm 10 \mathrm{mg} / \mathrm{dl}$ (diabetics on GCII) and $95 \mathrm{mg} / \mathrm{dl}$ (diabetic with the GCII interrupted); IRI $15 \pm 4 \mu \mathrm{U} / \mathrm{ml}, 20 \pm 7 \mu \mathrm{U} / \mathrm{ml}$, and $16 \mu \mathrm{U} / \mathrm{ml}$ respectively. The integrated insulin secretion rates from 0-90 min were $162 \pm 21 \mathrm{mU} / \mathrm{kg}$ (calculated secretion in normals) and $163 \pm 29$ (GCII dose in diabetics). The algorithm parameters used in GCII were individually estimated before induction of diabetes

normal PG pattern during IV glucose infusion (test 2). These curves were, however, normalised when at the beginning of each GCII the individual formula was fitted to the actual individual insulin responsiveness (tests 6-9). In most cases very high doses of insulin were necessary, in relation to Table 4 it should also be stressed, that different formulae can produce very similar PG curves but that an extreme enhancement of basal secretion in relation to the factors $a_{1}$ and $a_{2}$ leads to a distinctly reduced basal PG 
Table 5. Parameters of the plasma glucose and IRI curves, and need of insulin in a diabetic dog on glucose-controlled insulin infusions using different algorithm parameters. An additional IV glucose infusion of $60 \mathrm{~min}$ was given. The observations were done at weekly intervals (excepted that before diabetes). Experiments commenced at $0730 \mathrm{~h}$ ( $14 \mathrm{~h}$ after the last SC insulin injection), IV glucose was infused from $13.00 \mathrm{~h}$. The algorithm parameters applied in test 2 were the animals own individual regression coefficients resulting from test 1 [according to the formulae (1) and (2)]. The parameters used in test 3 and 4 were arbitrarily selected; those of the test 5-9 resulted from the adaptation of the original formula to the actual insulin responsiveness. For this the initial PG fall (rapidity and the level reached) was taken as a measure. Insulin half life was $3.0 \mathrm{~min}$ before test $1,2.6 \mathrm{~min}$ at the time of test 4, and $2.8 \mathrm{~min}$ after test 9 . Insulin antibodies were not detected at any time

\begin{tabular}{|c|c|c|c|c|c|c|c|c|c|}
\hline \multirow{2}{*}{$\begin{array}{l}\text { Expt. } \\
\text { no. }\end{array}$} & \multicolumn{3}{|c|}{ Algorithm parameters ${ }^{\mathrm{a}}$} & \multicolumn{3}{|c|}{ Plasma glucose } & \multicolumn{3}{|l|}{ Plasma IRI } \\
\hline & $\begin{array}{l}\mathrm{a}_{0} \\
{[\mathrm{mU} / \mathrm{kg} /} \\
\mathrm{min}]\end{array}$ & $\begin{array}{l}\mathrm{a}_{1} \\
{[\mathrm{mU} / \mathrm{kg} /} \\
\mathrm{min} / \\
\left.\mathrm{mg} \cdot \mathrm{dl}^{-1}\right]\end{array}$ & $\begin{array}{l}\mathrm{a}_{2} \\
{[\mathrm{mU} / \mathrm{kg} /} \\
\left.\mathrm{mg} \cdot \mathrm{dl}^{-1}\right]\end{array}$ & $\begin{array}{l}\text { Before GCII } \\
{[\mathrm{mg} / \mathrm{dl}]^{\mathrm{b}}}\end{array}$ & $\begin{array}{l}\text { Before IV } \\
\text { glucose } \\
{[\mathrm{mg} / \mathrm{dl}]^{\mathrm{c}}}\end{array}$ & $\begin{array}{l}\text { Reactive } \\
\text { area to IV } \\
\text { glucose }[\mathrm{mg} / \\
\mathrm{dl} \cdot 90 \mathrm{~min}]\end{array}$ & $\begin{array}{l}\text { Before GCII } \\
{[\mu \mathrm{U} / \mathrm{ml}]^{\mathrm{a}}}\end{array}$ & $\begin{array}{l}\text { At the end } \\
\text { of } \mathrm{GCII} \\
{[\mu \mathrm{U} / \mathrm{ml}]^{\mathrm{b}}}\end{array}$ & $\begin{array}{l}\text { Insulin dose } \\
\text { on } \mathrm{GCII} \\
{[\mathrm{mU} / \mathrm{kg} /} \\
90 \mathrm{~min}]\end{array}$ \\
\hline 1 & \multicolumn{3}{|c|}{ Before diabetes, no GCII } & - & 98 & 5688 & 19 & 69 & $163^{e}$ \\
\hline 2 & 0.76 & 0.015 & 0.156 & 411 & 100 & 8138 & 8 & 113 & 185 \\
\hline 3 & 1.52 & 0.031 & 0.156 & 366 & 59 & 9335 & 3 & 174 & 343 \\
\hline 4 & 0.38 & 0.008 & 0.078 & 416 & 121 & 11038 & 2 & 114 & 151 \\
\hline 5 & 0.72 & 0.118 & 0.576 & 370 & 106 & 7400 & 10 & 211 & 739 \\
\hline 6 & 0.75 & 0.123 & 0.600 & 462 & 110 & 6072 & 3 & 218 & 587 \\
\hline 7 & 1.05 & 0.172 & 0.840 & 420 & 105 & 5350 & 12 & 268 & 746 \\
\hline 8 & 0.98 & 0.160 & 0.780 & 430 & 98 & 5198 & 2 & 128 & 493 \\
\hline 9 & 1.12 & 0.187 & 0.913 & 391 & 99 & 4760 & 1 & 341 & 779 \\
\hline
\end{tabular}

For explanation see Table 4

b The mean of two analyses within $15 \mathrm{~min}$

${ }^{c}$ The mean of six analyses within $30 \mathrm{~min}$

d The mean of four analyses within $10 \mathrm{~min}$

e Calculated insulin secretion rate using formula (1)

level during GCII but does not improve glucose tolerance.

The influence of a GCII on the PG curve induced by a beef meal was investigated using the individual formulae (Fig. 6). In nondiabetic dogs there was no significant $P G$ alteration. In diabetics under GCII, however, a small but significant and longlasting PG increase occurred. This was presumably due to insufficient insulin delivery (Fig. 6, upper part). The amount infused was considerably smaller than the calculated insulin secretion rate in nondiabetic animals under these conditions.

\section{Application of the Present GCIIS in Diabetic Patients}

For the GCII-treatment of human diabetes the algorithm parameters could only be obtained from studies in healthy subjects (Table 6). Basal insulin secretion $\left(\mathrm{a}_{0}\right)$ did not vary significantly between OGTT and glucose infusions, but the glucose dependent part of insulin supply $\left(a_{1}, a_{2}\right)$ was higher when evaluated from the OGTT. Thus estimates from the mean normal OGTT curve were used.

In diabetic patients normoglycaemia was reached within $188 \pm 19 \mathrm{~min}$. This basal PG was $85 \pm 3 \mathrm{mg} /$ dl (Table 7). No hypoglycaemia occurred and glucose

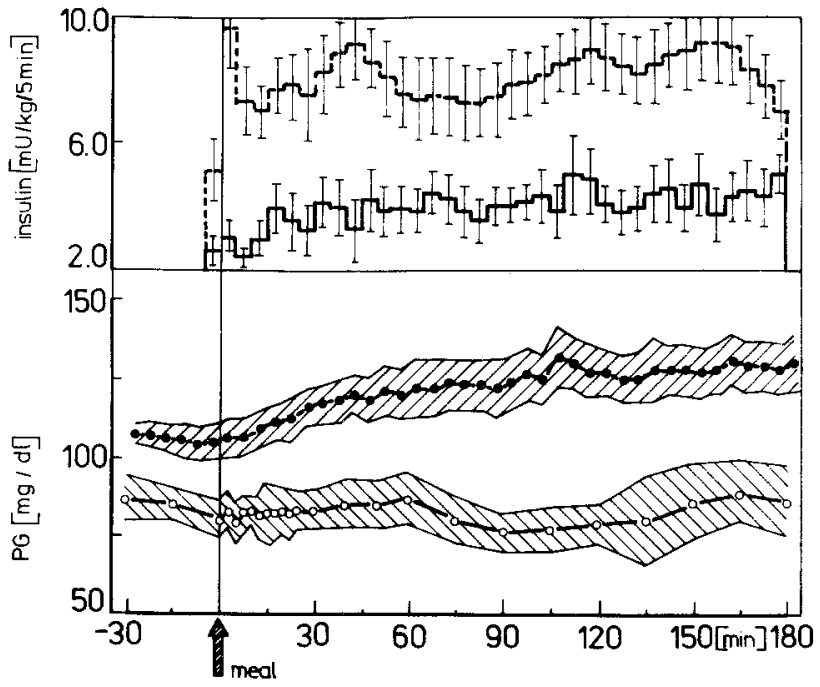

Fig. 6. Effect of a mixed meal on plasma glucose levels in normal dogs $(\mathrm{O}-\mathrm{O}, \mathrm{n}=11)$ and in diabetic animals on GCII $(-, \mathrm{n}$ $=8$ ). PG in the diabetic animals was normalised by GCII and maintained on a steady level for at least 30 min before the meal. The individually estimated algorithm parameters were used. The upper part shows the insulin secretion rates before diabetes (according to formula (1), - - - ; from 0 to $180 \mathrm{~min} 298 \pm$ $41 \mathrm{mU} / \mathrm{kg}$ were secreted) and the dosage pattern on GCII (from 0 to $180 \mathrm{~min} 143 \pm 22 \mathrm{mU} / \mathrm{kg}$ were infused, $\mathrm{p}<0.01$ for the difference) 
Table 6. Parameters of the multiple regression analysis between insulin secretion rates and the level and the rate of change of plasma glucose in normal men. Two groups of volunteers were investigated with an OGTT or an IV glucose infusion respectively as denoted in Table 1. See legend of Table 4 for further details. For the calculation of insulin secretion rate according to formula (1) the mean \pm SEM of the insulin half life $(3.6 \pm 0.2 \mathrm{~min})$ and of insulin space $(148 \pm 45 \mathrm{ml} / \mathrm{kg})$ of the diabetic patients were taken

\begin{tabular}{|c|c|c|c|c|c|c|c|}
\hline \multirow[t]{2}{*}{ Group } & \multirow{2}{*}{$\begin{array}{l}\text { Basal PG } \\
{[\mathrm{mg} / \mathrm{dl}]}\end{array}$} & \multirow[t]{2}{*}{ Test } & & \multicolumn{3}{|c|}{ Algorithm Parameters } & \multirow[b]{2}{*}{$\mathrm{R}$} \\
\hline & & & & $\begin{array}{l}\mathrm{a}_{0} \\
{[\mathrm{mU} / \mathrm{kg} / \mathrm{min}]}\end{array}$ & $\begin{array}{l}\mathrm{a}_{1} \\
{[\mathrm{mU} / \mathrm{kg} / \mathrm{min} / \mathrm{mg} \cdot \mathrm{dl}]}\end{array}$ & $\begin{array}{l}\mathrm{a}_{2} \\
{[\mathrm{mU} / \mathrm{kg} / \mathrm{mg} \cdot \mathrm{dl}]}\end{array}$ & \\
\hline$I(n=7)$ & 90 & OGTT & $\begin{array}{l}\text { Mean of all } \\
\text { individuals } \pm \mathrm{SEM} \\
\text { Mean curve }^{\mathrm{a}}\end{array}$ & $\begin{array}{l}0.55 \\
0.09 \\
0.54\end{array}$ & $\begin{array}{l}0.0145 \\
0.0023 \\
0.0157\end{array}$ & $\begin{array}{l}0.192 \\
0.048 \\
0.103\end{array}$ & - \\
\hline $\mathrm{II}(\mathrm{n}=8)$ & \pm 1 & $\begin{array}{l}\text { IV glucose } \\
\text { infusion }\end{array}$ & $\begin{array}{l}\text { Mean of all } \\
\text { individuals } \pm \text { SEM } \\
\text { Mean curve }\end{array}$ & $\begin{array}{l}0.56 \\
0.08 \\
0.71\end{array}$ & $\begin{array}{l}0.0089 \\
0.0014 \\
0.0077\end{array}$ & $\begin{array}{l}0.046 \\
0.016 \\
0.100\end{array}$ & $\begin{array}{l}- \\
0.94\end{array}$ \\
\hline
\end{tabular}

a This parameter set was used in the experiments presented in Figure 7

Table 7. Plasma glucose characteristics and insulin requirement of the patients on GCII

\begin{tabular}{|c|c|c|c|c|c|c|c|c|}
\hline \multirow{2}{*}{$\begin{array}{l}\text { Patient } \\
\text { no. }\end{array}$} & \multicolumn{4}{|c|}{ Plasma glucose $[\mathrm{mg} / \mathrm{dl}]$} & \multirow{2}{*}{$\begin{array}{l}\text { Duration of the } \\
\text { meal-induced } \\
\text { hyperglycaemia } \\
\text { [min] }\end{array}$} & \multicolumn{3}{|c|}{ Insulin requirement } \\
\hline & $\begin{array}{l}\text { Level at the } \\
\text { beginning }^{\mathrm{a}}\end{array}$ & $\begin{array}{l}\text { Fall during } \\
\text { the first hour }\end{array}$ & $\begin{array}{l}\text { Steady state } \\
\text { before meal }\end{array}$ & $\begin{array}{l}\text { Maximum after } \\
\text { the meal }{ }^{\mathrm{a}}\end{array}$ & & $\begin{array}{l}\text { for PG nor- } \\
\text { malisation in } \\
\text { the morning } \\
{[\mathrm{mU} / \mathrm{kg}]}\end{array}$ & $\begin{array}{l}\text { on } \mathrm{PG} \\
\text { steady state } \\
{[\mathrm{mU} / \mathrm{kg} \text {. }} \\
\mathrm{min}]\end{array}$ & $\begin{array}{l}\text { for compen- } \\
\text { sation of the } \\
\text { meal- } \\
\text { induced } \\
\text { hypergly- } \\
\text { caemia } \\
{[\mathrm{mU} / \mathrm{kg}]}\end{array}$ \\
\hline 1 & 229 & 25 & $89^{c}$ & - & - & 102 & 0.52 & - \\
\hline 2 & 204 & 80 & 77 & 155 & 175 & 80 & 0.34 & 104 \\
\hline 3 & 397 & 138 & $94^{d}$ & 168 & 175 & 226 & $-\mathrm{d}$ & 126 \\
\hline 4 & 498 & 165 & 101 & 155 & 240 & 309 & 0.71 & 162 \\
\hline 5 & 306 & 77 & 86 & 139 & 130 & 208 & 0.45 & 74 \\
\hline 6 & 143 & 37 & 83 & 139 & 170 & 45 & 0.43 & 97 \\
\hline 7 & 388 & 106 & $79^{c}$ & - & - & 287 & 0.37 & - \\
\hline 8 & 439 & 106 & $75^{\mathrm{c}}$ & - & - & 344 & 0.30 & - \\
\hline 9 & 261 & 127 & 84 & 172 & 210 & 85 & 0.46 & 168 \\
\hline 10 & 258 & 84 & 78 & 173 & 120 & 126 & 0.35 & 75 \\
\hline 11 & 339 & 129 & 100 & 168 & 180 & 183 & 0.70 & 137 \\
\hline 12 & 365 & 139 & $74^{c, d}$ & - & - & 185 & $--^{d}$ & - \\
\hline
\end{tabular}

a The mean of 3 determinations within $15 \mathrm{~min}$

b The mean of 6 determinations within $30 \mathrm{~min}$

c No meal given

d There was still the tendency to decrease when the meal was offered or the study interrupted respectively

was not infused. During this period immediately before the meals the mean insulin requirement was $1.23 \pm 0.10 \mathrm{mU} / \mathrm{kg} \cdot \min$. Insulin dosage and plasma glucose pattern were independent of the patients characteristics (Table 2) and of the pretest PG concentration.

When the patients were normoglycaemic they were given a mixed meal (Fig. 7). The resulting glucose profile showed a higher peak and delayed normalisation in comparison with those of normal subjects. The maximum PG value was the same in stable and in brittle diabetics (155 \pm 5 and $161 \pm 7 \mathrm{mg} / \mathrm{dl})$; "basal" levels were again reached after $169 \pm 15 \mathrm{~min}$ in both groups. In stable patients $6.8 \pm 1.1 \mathrm{IU}$ and in brittle patients $7.4 \pm 0.8$ IU insulin were given by GCII over the period of the meal. This was also less insulin than the calculated secretion rate in normal subjects. The three patients with insulin antibodies (Table 2) did not differ from the other diabetics in any GCII characteristics.

\section{Discussion}

The parameters of the present algorithm can be determined prospectively and individually. Its use in GCII provides the possibility to reach and to main- 
tain normal basal and post-glucose profiles of $P G$ and of IRI in the majority of diabetic subjects and to provide acceptable meal-time profiles. Long-term metabolic amelioration has also been attempted using this formula [11]; glucose administration to prevent hypoglycaemia was not necessary. In most cases normal blood concentrations of insulin could be kept.

Several algorithms have been used so far in artificial B-cells using electronic [7] or electromechanical $[27,28]$ equipment. The simplest tool is an on/off regulation as used earlier by Mirouze et al. [27]. Since this type clearly does not mimic the normal physiological response of B-cells it did not produce normal glucose profiles but considerable fluctuations.

Normally, glucose-stimulated insulin secretion in vitro exhibits saturation kinetics with a threshold phenomenon [25]. It also depends on the rate of change of glucose concentration [29]. A qualitatively similar pattern was demonstrated for the relationship of insulin concentration to the glucose level and to its rate of change in vivo [13]. Accordingly, Albisser et al. [3, 4] inaugurated the tanh function and Pfeiffer et al. [21, 32] used a fourth order parabola as an algorithm for the artificial B-cell. The parameters, however, can only be selected by experience and be optimised, if necessary, at random [5]. This uncertainty is more or less compensated by the different kinds of a dynamic or prospective consideration of any glucose alteration $[3,6,7,2122]$. Up to now, when applying these formulae it has often been necessary to infuse additional glucose in order to prevent hypoglycaemic episodes [24, 36].

The present algorithm was derived from the system of differential equations presented by Ackerman et al. [1]. After changing from IRI into the calculated insulin secretion rate, one of these equations was rearranged. A similar tool used by Kawamori et al. [20] is based on the regression analysis of the concentrations of glucose and of insulin and works with multiples of an independently assessed basal dose as an administration schedule. The metabolism of insulin and its action on glucose utilisation were also considered by Kruse-Jarres et al. [23] in simulating an extracorporal blood glucose regulating system. The basis of the algorithm described here is given by the calculation of insulin secretion rates. These figures do not correspond in all cases to those which are to be expected theoretically (see Fig. 4). The maximum difference was about $\pm 20 \%$. This is probably due both to the analytical error and to the variation of actual hepatic handling of insulin (F).

An artificial B-cell cannot completely replace the well-timed aminogenic and enterohormonally-mediated insulin secretion after a mixed meal or after

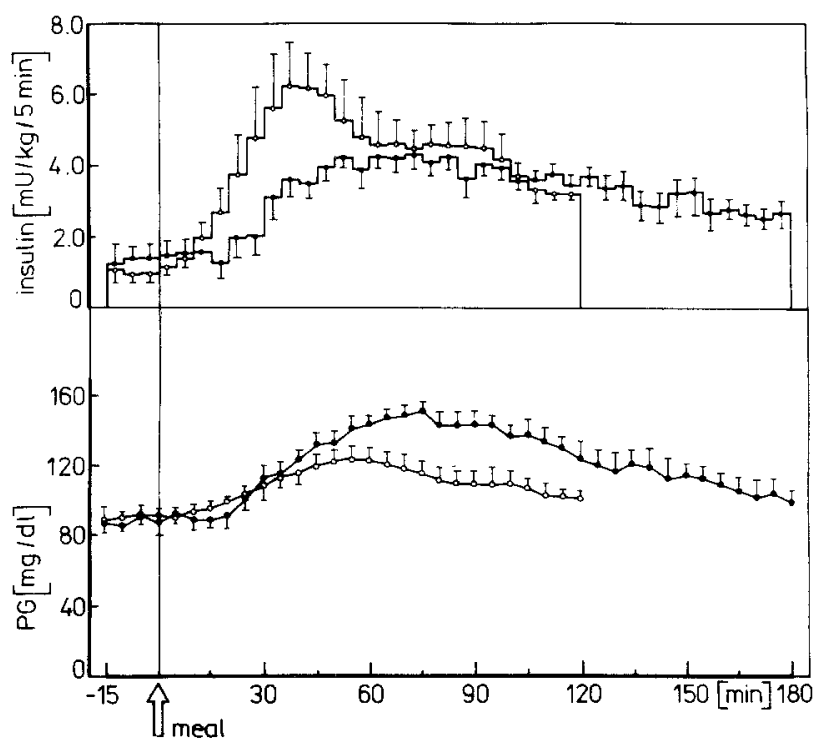

Fig. 7. Effect of a mixed meal on plasma glucose levels in normal men $(\mathrm{O}-\mathrm{O}, \mathrm{n}=5)$ and in diabetic patients on GCII $(-, \mathrm{n}$ $=8$ ). PG in the diabetics was normalised before the meal by GCII. The algorithm parameters of a "general man" (resulting from normal OGTT, see Table 6) were used. The upper part shows the insulin secretion rates [according to formula (1)] before diabetes and the insulin dosage pattern on GCII

intake of the typical canine food consisting mainly of proteins (Fig. 6 and 7). This is probably partly compensated by the so-called dynamic control parameters of the algorithm [21,32]. Accordingly the importance of appropriate parameters for an early immediate reaction of insulin dosage has already been shown by Albisser et al. [4] in all situations with an increasing glycaemia. In the present system this function is fulfilled by $a_{2}$. Its linear consideration does not delay the normalisation of hyperglycaemic values and it does not produce inappropriate oscillations under basal conditions. However, better timing of the measuring and dosage intervals should further improve the results.

One of the basic problems in estimating the algorithm parameters is that of individualisation [26]. GCII does not primarily need individual formulae as has already been suggested by Horwitz et al. [18]. From the clinical viewpoint especially the apparently glucose-independent need of insulin $\mathrm{a}_{0}$ must be taken into consideration [19]. It represents more or less the basal insulin requirement which is obviously connected with the actual insulin responsiveness [15]. The latter can vary considerably from day to day [11]. This basal rate (calculated as $a_{o}$ or really applied in GCII) is higher than often assumed (see Tables 6 and 7). Similar observations were obtained using the Biostator ${ }^{\circledR}$. This is based on the fact that normally 
hyperglycaemia-independent factors stimulate additionally insulin secretion and that in GCII insulin dosage is required by all minor glycaemic alterations.

In this study there was a great variability both of $a_{o}$ and of glucose-dependent insulin supply $\left(a_{1}, a_{2}\right)$. The glycaemic reaction in GCII depended clearly also on the actual parameter value chosen and some diabetic would not manage with the algorithm constants as primarily estimated (see Table 5). Plasma insulin levels have always been proportionally related to insulin dosage (Table 5). Additionally in the literature no clear differences in insulin metabolism between normal and insulin-dependent diabetic subjects have been reported $[30,33]$. Thus the different GCII effects are probably due to varying insulin sensitivity and the parameters should be adapted during the initial phase of a GCII. One approach to such adaptation is presented in Table 5 (tests 5-9) where the ratio of the mean insulin dose in PG steady state with the original formula to the theoretical basal insulin dose was used as a reinforcing factor during the further GCII run.

According to our experience in the diabetic patients a similar therapeutic rule is feasible starting with the mean parameters of a "normal man". More information is, however, needed on the relation of the metabolic effect of a parameter to the patient's data (e. g. degree of obesity, acute or chronic stress reactions, quality of preceding metabolic control). According to these preliminary results the applicability of a GCIIS does not strongly depend on the existence of a brittle or a more stable metabolic type or on the occurrence of insulin antibodies.

Our previous observations in diabetic dogs on GCII of a distinct and reproducible circadian pattern of plasma glucose $[8,11]$ points additionally to the necessity to adapt the algorithm parameters. There were similar findings in man. These results correspond well to the attachment of the glucoregulatory system to the circadian phase pattern of man [39]. It could be expected that time-dependent algorithms determined from such observations could provide the function principle for a more simple version of automated insulin therapy like the pre-programmed open-loop system $[2,14,18,31]$.

Acknowledgements. The skilful technical assistance of Mrs. Karla Brüllke, Mrs. Helga Schröder, Mrs. Hannelore Buff, Mrs. Erika Kedrowski, Mrs. Renate Knigge, Mrs. Dagmar Jahr, and Miss Ute Mönnich is greatfully acknowledged.

\section{References}

1. Ackerman E, Rosevaer J W, McGuckin W F (1964) A mathematical model of the glucose tolerance test. Phys Med Biol 9: 203-213
2. Albisser A M, Jackman W S, Ferguson R, Bahoric A, Goriya Y (1978) A portable precision pumping system for chronic, programmed insulin infusion. Med Prog Technol 5: 187-193

3. Albisser A M, Leibel B S, Ewart T G, Davidovac Z, Botz C K, Zingg W (1974) An artificial endocrine pancreas. Diabetes 23: 389-396

4. Albisser A M, Leibel B S, Ewart T G, Davidovac Z, Botz C K, Zingg W, Schipper H, Gander R (1974) Clinical control of diabetes by the artificial pancreas. Diabetes 23: 397-404

5. Albisser A M, Leibel B S, Zingg W, Botz CK, Marliss E B, Denoga A, Zinman B (1977) The development of an artificial endocrine pancreas and its application in research and clinical investigation. Horm Metab Res [Suppl] 7: 87-94

6. Botz C K (1976) An improved control algorithm for artificial B-cell. IEEE Trans Biomed Eng 23: 252-255

7. Clemens A H, Chang P H, Myers R W (1977) The development of a Biostator, a glucose controlled insulin infusion system (GCIIS). Horm Metab Res [Suppl] 7: 23-33

8. Fischer U, Albrecht G, Jutzi E, Becker G, Freyse E-J, Unger W, Heil M (in press) Zirkadiane Rhythmen von Plasmaglucose und -insulin bei diabetischen Hunden unter dem Einfluß einer kontinuierlichen meßwertabhängigen Insulininfusion. Stud Biophys

9. Fischer U, Hommel H, Gottschling H-D, Heinke P, Jutzi E (1975) Estimation of pancreatic IRI output rate and its relation to glucose tolerance in normal anaesthetised dogs. Diabetologia 11: 291-299

10. Fischer U, Hommel H, Ziegler M, Michael R (1972) The mechanism of insulin secretion after oral glucose administration. Diabetologia 8: 104-110

11. Fischer U, Jutzi E, Freyse E-J, Salzsieder E (1978) Derivation and experimental proof of a new algorithm for the artificial Bcell based on the individual analysis of the physiological insulin-glucose relationship. Endokrinologie 71: 65-75

12. Fischer U, Jutzi E, Hommel H, Gottschling H-D, Salzsieder E, Fejéregyhazi I, Albrecht G (1978) Pancreatic and hepatic balances of insulin and of glucose in the anesthetised dog under steady-state and non-steady-conditions. Acta Biol Med Ger 37: 1049-1064

13. Foster R O, Soeldner J S, Tan M H, Guyton J R (1973) Short term glucose homeostasis in man: a systems dynamics model. J Dynam Syst (Trans ASME) 95: 308-314

14. Genuth S, Martin P (1977) Control of hyperglycemia in adult diabetics by pulsed insulin delivery. Diabetes 26: 571-581

15. Hepp K D, Buchholz E, Renner R, von Funcke M J, Mehnert H, Franetzki M, Kresse H (1979) Programmierte kontinuierliche Insulininfusionen zur Diabeteseinstellung. Klin Wochenschr 57: 117-124

16. Horwitz D L, Gonen B, Zeidler A, Langer B, Rodman D (1977) An "artificial beta cell" for control of diabetes. Comparison of glucose and free insulin levels with those achieved by subcutaneous insulin. Diabetes 26:376

17. Horwitz D L, Rodman D, Langer B (1978) Algorithm flexibility in an artificial beta-cell for control of diabetes. Diabetes 27: 482

18. Irsigler K, Kritz H (1979) Long-term continuous intravenous insulin therapy with a portable insulin dosage-regulating apparatus. Diabetes 28: 196-203

19. Katsch G (1937) Garzer Thesen. Zur Ernährungsführung der Zuckerkranken. Klin Wochenschr 16: 399-403

20. Kawamori R, Shichiri M, Goriya Y, Yamasaki Y, Shigeta Y, Abe $H$ (1978) Importance of insulin secretion based on the rate of change in blood glucose concentration in glucose tolerance, assessed by the artificial beta cell. Acta Endocrinol (Kbh) 87: 339-351

21. Kerner W, Thum Ch, Tamas jr, G, Beischer W, Clemens A H, Pfeiffer E F (1976) Attempts at perfect normalization of glu- 
cose tolerance test of severe diabetics by artificial beta cell. Horm Metab Res 8: 256-261

22. Kraegen E W, Campbell L V, Chia Y O, Meler H, Lazarus L (1977) Control of blood glucose in diabetics using an artificial pancreas. Aust NZ J Med 7: 280-286

23. Kruse-Jarres J D, Braun G, Bresch M, Lehmann U, Letulé U, Naegele R, Winkelman R (1979) Die extrakorporale Blutglukoseregulierung. Med Welt 30: 83-88

24. Lambert A E, Buysschart M, Marchand E, Pierard M, Wojcik S, Lambotte L (1978) Determination of insulin requirements in brittle diabetic patients by the artificial pancreas. Diabetes 27: 825-833

25. Malaisse W, Malaisse-Lagae F, Wright PH (1967) A new method for the measurement in vitro of pancreatic insulin secretion. Endocrinology 80: 99-108

26. Marliss E B, Murray FT, Stokes EF, Zinman B, Nakhooda A F, Denoga A, Leibel B S, Albisser A M (1977) Normalization of glycemia in diabetics during meals with insulin and glucagon delivery by the artificial pancreas. Diabetes 26: $663-672$

27. Mirouze J, Selam J L, Chi P PT (1976) Infusion insulinique par débit asservi a l'enregistrement glycémique continu. Journ Annu Diabetol Hôtel Dieu 16: 303-312

28. Mirouze J, Selam J L, Pham T C, Cavadore D (1977) Evaluation of exogenous insulin homeostasis by the artificial pancreas in insulin-dependent diabetics. Diabetologia 13: 273-278

29. O'Connor M D L, Landahl H D, Grodsky G M (1977) Role of rate of change of glucose concentration as a signal for insulin release. Endocrinology 101: 85-89

30. Parsons J A (1976) Endocrine pharmacology. In: Parsons J A (ed.) Peptide hormones. Macmillan Press Ltd., London, $\mathrm{p}$ $67-82$

31. Pickup J C, Keen H, Parsons J A, Alberti K G MM (1978) Continuous subcutaneous insulin infusion: an approach to achievement of normoglycemia. Br Med J I: 204-207

32. Pfeiffer EF, Beischer W, Kerner W (1977) The artificial endocrine pancreas in clinical research. Horm Metab Res [Suppl] 7: 95-114

33. Pierluissi J, Norwich K H, Green GR, Campbell J (1978) Insulin kinetics in metasomatotropic diabetes. Metabolism 27: $61-70$

34. Salzsieđer E, Wilke W, Freyse E-J, Fischer U (1979) Ein Gerät zur programmierten Ansteuerung von Infusionspumpen und sein Einsatz im Tierexperiment. Z Med Lab Diagn 20: $42-50$

35. Sherwin R S, Kramer K J, Tobin J D, Insel P A, Liljenquist J E, Berman M, Andres R (1974) A model of the kinetics of insulin in man. J Clin Invest 53: 1481-1492

36. Slama G, Klein J C, Tardieu M-C, Tchobroutsky G (1977) Normalisation de la glycémie par pancréas artificiel non miniaturisé. Application pendant 24 heures chez 7 diabétiques insulino-dépendants. Nouv Presse Med 6: 2309-2313

37. Vinik A I, Kalk W J, Botha J L, Jackson W P U, Blake K C H (1976) The inexhaustible beta cell. Diabetes 25: 11-15

38. WMA (1973) Ethical declarations Helsinki. Br Med J I: $687-688$

39. Wojtczak-Jaroszowa J (1978) Physiological and clinical aspects of circadian variations in glucose tolerance. Chronobiologia 4: 363-384

40. Ziegler M, Michael R, Hommel H, Klatt D (1972) The influence of hemolysis on radioimmunoassay of insulin and its prevention by pre-incubation with anti-insulin serum. J Clin Endocrinol Metab 35: 317-318

Received: January 1, 1979,

and in revised form: July 24, 1979

Dr. U. Fischer

Central Institute for Diabetes

"Gerhard Katsch"

DDR-2201 Karlsburg

German Democratic Republic 